\title{
Adolescent Tillaux Fractures: A Systematic Review of the Literature
}

\author{
Sameem Tak ${ }^{1}$, Mobeen K. Qureshi ${ }^{2}$, James A. Ackland ${ }^{3}$, Rizwan Arshad ${ }^{4}$, Javed Salim ${ }^{4}$ \\ 1. Trauma and Orthopaedics, University Hospitals of Leicester, Leicester, GBR 2. Trauma and Orthopaedics, East \\ Lancashire NHS Hospitals, Blackburn, GBR 3. Psychology, University of Cambridge, Cambridge, GBR 4. Trauma and \\ Orthopaedics, Hull University Teaching Hospitals NHS Trust, Hull, GBR
}

Corresponding author: Sameem Tak, s.tak@nhs.net

\begin{abstract}
The Tillaux fracture is an uncommon injury to the anterolateral distal tibial epiphysis. It occurs during a distinct time period when adolescent patients are transitioning to skeletal maturity. Owing to its rarity, the optimal management strategy for this fracture is not well-described. The aim of this review was to assess the outcomes of operatively and nonoperatively managed displaced adolescent Tillaux fractures. We analysed articles from The Cochrane Library, PubMed, MEDLINE, and EMBASE databases that met our predetermined inclusion and exclusion criteria according to Preferred Reporting Items for Systematic Reviews and MetaAnalysis (PRISMA) statements. A descriptive data analysis was performed. A total of 461 articles were identified from the data search, of which 13 articles were included for full-text analysis. Five of these studies reported recognised patient outcome measures and the remaining eight reported on radiographic follow-up. The reported studies included a total of 114 patients with Tillaux fractures; $58.8 \%$ of patients were female and $34.2 \%$ were male. Mean ages ranged from 12.5 to 15 years, with the youngest patient being 12 years old and the oldest 17 years old. Overall mean follow-up was 42.8 months. Of the patients, $40.4 \%$ were treated with open reduction internal fixation (ORIF), $14.9 \%$ with closed reduction internal fixation (CRIF), and 1.8\% arthroscopically. The remainder were treated nonoperatively. Outcome measures were excellent for all patients irrespective of operative management choice. Follow-up radiographic deformity was only evident in Tillaux fractures that were managed nonoperatively; deformity included poor joint congruity, angular deformity, and tibial shortening. These nonoperative patients have a residual fracture displacement of 2 $\mathrm{mm}$. There were no reported instances of premature physeal closure for any patient. This review shows that excellent patient outcomes have been reported for different methods of operative fixation, however, study sizes are small and data is sparse. Further robust comparative studies are required to identify definitive conclusions. The use of established clinical and radiographic outcome measures will help improve the quality of future studies for this relatively rare injury.
\end{abstract}

Categories: Orthopedics, Trauma

Keywords: tillaux, fracture, ankle, orthopaedic, transitional, adolescent, juvenile

Review began 12/29/2020 Review ended 01/14/2021 Published 01/22/2021

๑) Copyright 2021 Tak et al. This is an open access article distributed under the terms of the Creative Commons Attribution License CC-BY 4.0., which permits unrestricted use, distribution, and reproduction in any medium, provided the original author and source are credited.

\section{Introduction And Background}

Sir Astley Cooper first described a fracture of the lateral tibial plafond in 1822 [1]. Paul Jule Tillaux then defined an experimental mechanism for the occurrence of this fracture in 1876, in which the pull of the anterior inferior tibiofibular ligament caused an avulsion fracture of the distal tibia in adult cadavers [2]. Henry Chaput subsequently demonstrated the radiographic appearances of this fracture in 1899 [3]. The Chaput tubercle can be seen as the insertion site of the anterior inferior tibiofibular ligament at the anterolateral aspect of the distal tibia. When fractured, the lesion is most commonly referred to as a Tillaux fracture and occasionally as a Tillaux-Chaput fracture. The initial description of this injury was in adults, with occurrence in the adolescent population being referred to as the juvenile Tillaux fracture. In 1964, Kleiger and Mankin were the first to report on a series of adolescent patients with this injury [4].

Both Tillaux and Triplane fractures of the distal tibial epiphysis are referred to as transitional fractures because they occur during an 18-month period of transition from skeletal immaturity to maturity [5]. The distal tibial physis closes between 12 and 17 years in females and 15 and 20 years in males. This closure occurs in a predictable asymmetrical pattern, beginning centrally, then anteromedially, posteromedially and, finally, laterally; whilst the lateral aspect of the physis is open, it is vulnerable to injury [6-10]. The mechanism leading to a Tillaux fracture is usually forced external rotation of the foot, resulting in a SalterHarris type III epiphyseal injury [11-12].

Tillaux fractures are consequently rarely seen in adults since the anterior inferior tibiofibular ligament is more likely to rupture than to avulse a bony fragment at its attachment site [13-14]. The incidence of Tillaux fractures is $2.9 \%$ of juvenile epiphyseal growth plate injuries [15]. Radiographic workup includes anteroposterior, lateral and mortise view radiographs [16]. Computed tomography )CT) scans have been shown to be more sensitive in detecting Tillaux fracture displacement $>2 \mathrm{~mm}$ compared to radiographs [17]. 
Since these injuries are intra-articular with growth plate involvement, the surgeon's aim is to achieve an anatomic reduction of the joint surface to minimise the risk of post-traumatic arthritis, pain and stiffness [18]. Treatment strategy depends on displacement; minimally displaced fractures $(<2 \mathrm{~mm})$ are often treated non-operatively by cast immobilisation, and displacement $\geqslant 2 \mathrm{~mm}$ is generally an indication for operative repair [9-10].

There is limited data to support a consensus on displaced Tillaux fracture management. Reports in the literature often group Tillaux and triplane fracture data together (the transitional fractures) and many studies are limited by small sample size or lack of validated functional outcome measure use. The aim of this paper was to review the outcomes of operatively and nonoperatively managed displaced adolescent Tillaux fractures.

\section{Review}

\section{Methods: search strategy}

An online systematic literature search in accordance with the Preferred Reporting Items for Systematic Reviews and Meta-Analyses (PRISMA) guidelines was performed. The Cochrane Library was searched, and the National Institute for Health and Care Excellence (NICE) healthcare database advanced search (HDAS) was utilised via OpenAthens to search the PubMed, MEDLINE and EMBASE databases. The search was performed using Boolean operators and the wildcard symbol (*) to truncate search terms for Tillaux OR Tillaux-Chaput OR distal tibia* epiphys* OR anterolateral distal tibial OR transitional OR Kleiger AND fracture* AND child* OR teen* OR adolescen* OR juvenile. The databases were searched from their inception until October 2020. All reference lists of included articles were trawled for further relevant studies missed by the search. EndNote version X9 (Thomas Reuters, New York City, NY) was used to organise the database searches and to filter duplicate articles. Unpublished work was not sought.

\section{Methods: eligibility criteria}

Studies were included if they reported: any original article, age $<18$ years old with an isolated Tillaux fracture of any management strategy, such as nonoperative, open reduction internal fixation (ORIF), closed reduction internal fixation (CRIF) or arthroscopic, and stated follow-up with a standardised patient outcome measure such as American Orthopaedic Foot \& Ankle Society (AOFAS), Foot and Ankle Outcome Score (FAOS), Modified Weber Protocol (MWP) [19-22] or radiographic follow-up (union rate, premature physeal closure, fracture healing, joint incongruity, angular deformity).

Studies that were excluded were: case reports, case series $<2$ patients, review articles, basic science articles, patients aged $>18$ years old, triplane fractures, cadaveric studies, Tillaux fractures with an associated lower limb injury, studies reporting Salter-Harris III fractures without explicit identification of Tillaux fractures, reports with unstandardised descriptive follow-up and incomplete data sets. The language of publication was limited to English.

\section{Methods: data extraction and statistical analysis}

Following initial duplication removal, titles and abstracts for 340 articles identified through the database search were screened independently by two authors against the inclusion and exclusion criteria. This was achieved in a parallel blinded manner by using the Rayyan QCRI tool for screening abstracts [23]. Where there was uncertainty on an article's suitability for inclusion, full texts were obtained and reviewed. There was no disagreement in study selection between authors.

The following data were extracted: demographics for the number of patients, age, gender, indication for surgery, fracture management choice, outcome measure, radiographic outcome and follow-up length of time. Appendix A shows the quality assessment tool that was used to assess the risk of bias of the included studies, adapted from Murad et al. for case series and ROBINS-I for non-randomised interventional studies [24-25]. All continuous data were pooled and descriptive data analysis performed.

\section{Results}

The preliminary literature search yielded 461 articles, of which 13 were put forward for analysis. Figure 1 shows the PRISMA flowchart for study selection. No further unique articles were found from trawling citations of included articles. Twenty-three full-text articles were deemed ineligible for inclusion in the review; the reasons for their exclusion are summarised in Appendix B. 


\section{Cureus}

PRISMA 2009 Flow Diagram
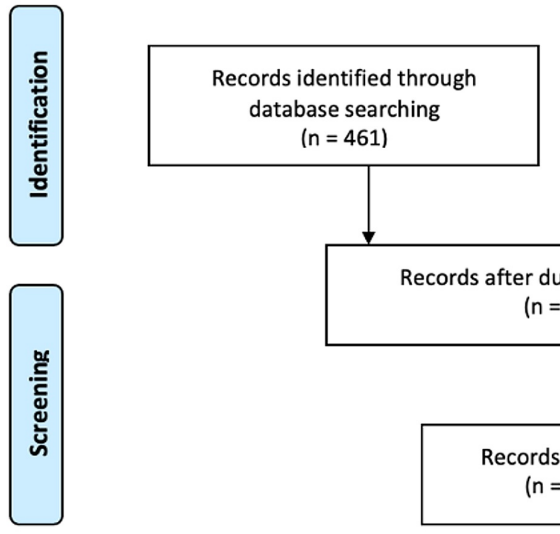
( $n=461$ )

Additional records identified through other sources<smiles>CCC</smiles>
$(\mathrm{n}=0)$
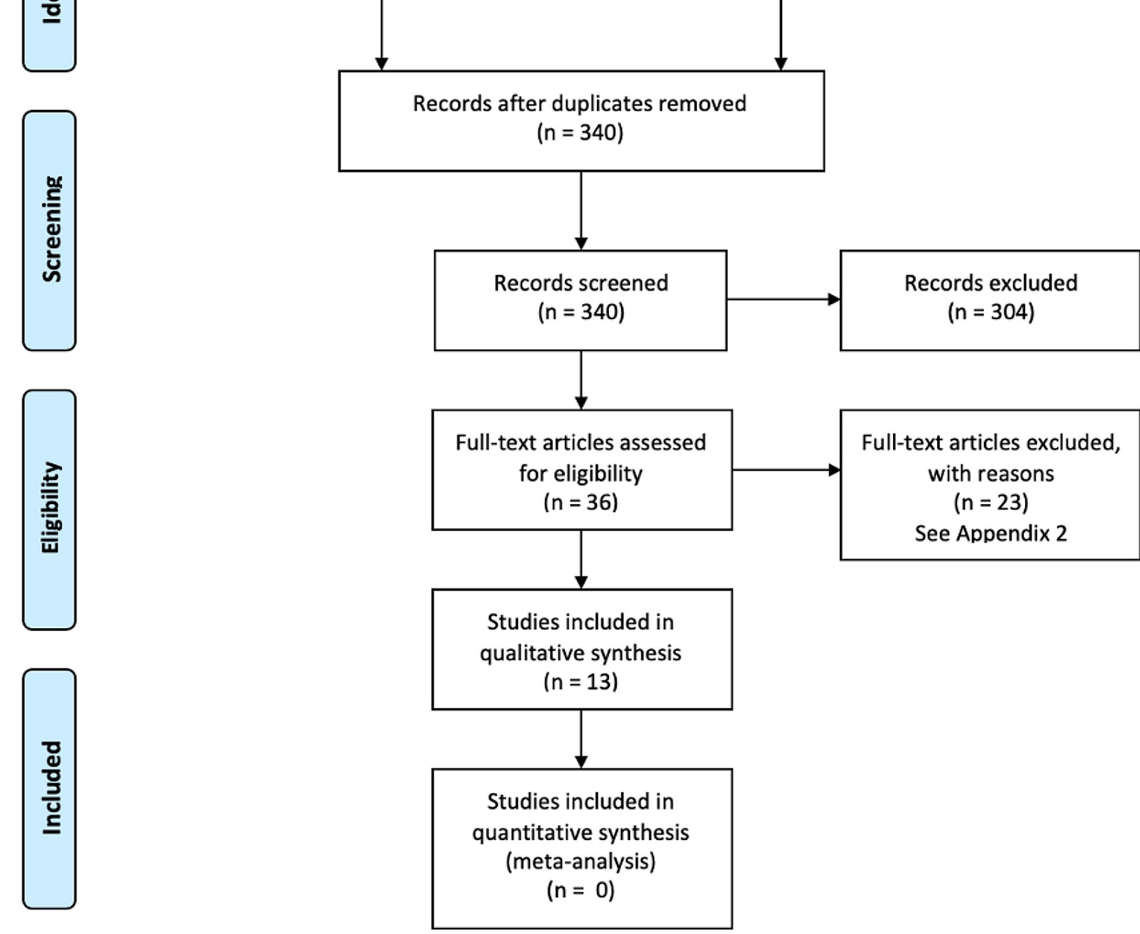

FIGURE 1: Flow diagram of Preferred Reporting Items for Systematic Reviews and Meta-Analyses (PRISMA) strategy used to determine eligible studies

Only five of the 13 included articles used substantiated patient-reported outcome measures [26-30]. The remaining eight articles reported radiographic follow-up only [11-12,31-36]. The included studies were either case series or uncontrolled cohort studies.

Table 1 summarises the characteristics of the studies included in our analysis. The 13 studies contributed a total of 114 patients, $58.8 \%(n=67)$ of which were female and $34.2 \%(n=39)$ of which were male. Mean ages ranged from 12.5 to 15 years, with the youngest patient being 12 years old and the oldest 17 years old. Twelve of the 13 studies reported a mean follow-up period; the overall mean follow-up was 42.8 months, ranging from six months to 27 years. 


\section{Cureus}

\begin{tabular}{|c|c|c|c|c|c|c|c|c|c|}
\hline Author & Year & Study design & $\begin{array}{l}\text { Number } \\
\text { of } \\
\text { patients }\end{array}$ & $\begin{array}{l}\text { Gender } \\
\text { male/female }\end{array}$ & $\begin{array}{l}\text { Mean } \\
\text { age } \\
\text { (years) }\end{array}$ & $\begin{array}{l}\text { Age } \\
\text { range } \\
\text { (years) }\end{array}$ & Indication for surgery & $\begin{array}{l}\text { Mean follow } \\
\text { up (months) }\end{array}$ & $\begin{array}{l}\text { Follow up } \\
\text { range } \\
\text { (months) }\end{array}$ \\
\hline $\begin{array}{l}\text { Al-Ashhab \& } \\
\text { Mohamed [26] }\end{array}$ & 2019 & $\begin{array}{l}\text { single-arm, } \\
\text { uncontrolled cohort } \\
\text { study }\end{array}$ & 13 & $4 / 9$ & 13.4 & $12-17$ & $\begin{array}{l}>2 \mathrm{~mm} \text { fracture } \\
\text { displacement }\end{array}$ & 41.7 & $24-60$ \\
\hline Kim et al. [27] & 2010 & case series & 2 & $2 / 0$ & 12.5 & $12-13$ & - & 15 & $12-18$ \\
\hline $\begin{array}{l}\text { Tiefenbock et } \\
\text { al. [28] }\end{array}$ & 2016 & case series & 7 & $4 / 3$ & 15 & $14-16$ & $\begin{array}{l}>2 \mathrm{~mm} \text { fracture } \\
\text { displacement }\end{array}$ & 79 & $40.43-126.80$ \\
\hline Feng et al. [29] & 2018 & case series & 2 & 1/1 & 13 & $10-16$ & $\begin{array}{l}>2 \mathrm{~mm} \text { fracture } \\
\text { displacement }\end{array}$ & 17.5 & $15-20$ \\
\hline Kaya et al. [30] & 2007 & case series & 10 & $4 / 6$ & 13.1 & $12-14$ & $\begin{array}{l}2 \mathrm{~mm} \text { or more fracture } \\
\text { displacement }\end{array}$ & 54 & $32-75$ \\
\hline $\begin{array}{l}\text { Gourineni \& } \\
\text { Gupta [33] }\end{array}$ & 2011 & case series & 8 & - & 12.9 & $10-14$ & $\begin{array}{l}>1 \mathrm{~mm} \text { fracture } \\
\text { displacement }\end{array}$ & 12 & - \\
\hline $\begin{array}{l}\text { Leary et al. } \\
\text { [35] }\end{array}$ & 2009 & case series & 26 & $12 / 14$ & 13.5 & - & $\begin{array}{l}>2 \mathrm{~mm} \text { fracture } \\
\text { displacement }\end{array}$ & 8.47 & - \\
\hline $\begin{array}{l}\text { Dailiana et al. } \\
\text { [31] }\end{array}$ & 1999 & case series & 3 & $2 / 1$ & 14 & 13-15 & - & 56 & 18-102 \\
\hline $\begin{array}{l}\text { Stefanich \& } \\
\text { Lozman [11] }\end{array}$ & 1986 & case series & 5 & $0 / 5$ & 12.8 & $12-15$ & $\begin{array}{l}2 \mathrm{~mm} \text { or more fracture } \\
\text { displacement }\end{array}$ & 64.8 & $12-108$ \\
\hline $\begin{array}{l}\text { Landin et al. } \\
\text { [34] }\end{array}$ & 1986 & case series & 17 & 3/14 & 13.9 & $12-16$ & - & 112.2 & 36-324 \\
\hline $\begin{array}{l}\text { Dias \& } \\
\text { Giegerich [32] }\end{array}$ & 1983 & case series & 9 & $3 / 6$ & 13.5 & $12-14$ & $\begin{array}{l}>2 \mathrm{~mm} \text { fracture } \\
\text { displacement }\end{array}$ & - & $18-36$ \\
\hline $\begin{array}{l}\text { Spiegel et al. } \\
\text { [12] }\end{array}$ & 1978 & case series & 6 & $3 / 3$ & 13.5 & - & all nonoperative & 40.8 & - \\
\hline $\begin{array}{l}\text { Molster et al. } \\
\text { [36] }\end{array}$ & 1977 & case series & 6 & $1 / 5$ & 14.7 & 13-16 & $\begin{array}{l}\text { moderate vs. minimal } \\
\text { displacement, not } \\
\text { quantified }\end{array}$ & 12.2 & 6-21 \\
\hline
\end{tabular}

TABLE 1: Study characteristics

Note: Unrecorded data are represented by '-'

In total, $40.4 \%(\mathrm{n}=46)$ of patients were treated with ORIF, $14.9 \%(\mathrm{n}=17)$ with CRIF and $1.8 \%(\mathrm{n}=2)$ arthroscopically. Four point four percent $(4.4 \% ; n=5)$ did not specify the operative treatment and $38.6 \%$ $(\mathrm{n}=44)$ of patients were treated nonoperatively.

Table 2 shows the five studies that used recognised standardised patient outcome measure scores; three used AOFAS, one used the MWP and one used FAOS. Within these five studies, 55.9\% ( $\mathrm{n}=19)$ were ORIF, $38.2 \%(n=13)$ were CRIF and 5.9\% $(n=2)$ were arthroscopic. All five of these studies reported excellent scores for all patients regardless of operative management choice. 


\section{Cureus}

\begin{tabular}{|c|c|c|c|c|c|c|}
\hline Author & Year & ORIF & CRIF & Arthroscopic & Outcome measure & Cast immobilisation length \\
\hline Al-Ashhab \& Mohamed [26] & 2019 & 3 & 10 & - & mean AOFAS 97 (range 95-100) & 6 weeks NWB \\
\hline Kim et al. [27] & 2010 & - & 2 & - & mean MWP Excellent & - \\
\hline Tiefenbock et al. [28] & 2016 & 6 & 1 & - & mean foot and ankle score 98.71 & 4-8 weeks \\
\hline Feng et al. [29] & 2018 & - & - & 2 & mean AOFAS 92 & 6 weeks NWB \\
\hline Kaya et al. [30] & 2007 & 10 & - & - & mean AOFAS 99.3 (range 97-100) & 6 weeks \\
\hline
\end{tabular}

\section{TABLE 2: Five studies that used standardised patient outcome measures}

ORIF, open reduction internal fixation; CRIF, closed reduction internal fixation; AOFAS, American Orthopaedic Foot \& Ankle Society; MWP, Modified Weber Protocol

Table 3 shows the 80 patients with radiographic follow-up. All patients treated with either ORIF (33.8\%, $\mathrm{n}=27$ ) or CRIF (5\%, $\mathrm{n}=4)$ showed excellent radiographic follow-up outcomes. Four patients who were treated nonoperatively had radiographic deformity at follow-up, including joint incongruity, tibial shortening, valgus deformity and angulation. Three of these patients had no attempt at fracture reduction performed and had a residual gap of $2 \mathrm{~mm}$ fracture displacement [34]. The authors of the patient with joint incongruity did not comment upon fracture displacement [12]. 


\section{Cureus}

\begin{tabular}{|c|c|c|c|c|c|c|c|c|}
\hline Author & Year & Nonoperative & ORIF & CRIF & Arthroscopic & $\begin{array}{l}\text { Operative } \\
\text { unspecified }\end{array}$ & Radiographic follow-up & $\begin{array}{l}\text { Cast } \\
\text { immobilisation } \\
\text { length }\end{array}$ \\
\hline $\begin{array}{l}\text { Gourineni } \\
\text { \& Gupta } \\
\text { [33] }\end{array}$ & 2011 & - & 5 & 3 & - & - & $\begin{array}{l}\text { all fractures healed radiographically within } 4 \\
\text { weeks }\end{array}$ & 4 weeks \\
\hline $\begin{array}{l}\text { Leary et } \\
\text { al. [35] }\end{array}$ & 2009 & 21 & - & - & - & 5 & $0 \%$ of radiographic PPC & - \\
\hline $\begin{array}{l}\text { Dailiana } \\
\text { et al. [31] }\end{array}$ & 1999 & - & 3 & - & - & - & all fractures healed radiographically & 4 weeks \\
\hline $\begin{array}{l}\text { Stefanich } \\
\text { \& } \\
\text { Lozman } \\
\text { [11] }\end{array}$ & 1986 & 1 & 4 & - & - & - & all fractures healed anatomically & 6-9 weeks \\
\hline $\begin{array}{l}\text { Landin et } \\
\text { al. [34] }\end{array}$ & 1986 & 10 & 6 & 1 & - & - & $\begin{array}{l}\text { ORIF: normal CRIF: normal no reduction: } 3 \\
\text { cases with radiographic abnormality (1: } \\
\text { valgus deformity of } 5 \text { degrees and } 17 \mathrm{~mm} \text { tibial } \\
\text { shortening, 2: } 5 \text { degrees of anterior } \\
\text { angulation, } 3: 6 \text { degrees of dorsal angulation) } \\
\text { all } 3 \text { had residual fracture displacement of } \\
2 \mathrm{~mm}\end{array}$ & 4-6 weeks \\
\hline $\begin{array}{l}\text { Dias \& } \\
\text { Giegerich } \\
\text { [32] }\end{array}$ & 1983 & 5 & 4 & - & - & - & all fractures healed radiographically & 6 weeks \\
\hline $\begin{array}{l}\text { Spiegel } \\
\text { et al. [12] }\end{array}$ & 1978 & 6 & - & - & - & - & $\begin{array}{l}1 \mathrm{x} \text { joint incongruity (only } 4 / 6 \mathrm{pts} \text { for follow } \\
\text { up) }\end{array}$ & - \\
\hline $\begin{array}{l}\text { Molster } \\
\text { et al. [36] }\end{array}$ & 1977 & 1 & 5 & - & - & - & no radiographic deformity & 5-7 weeks \\
\hline
\end{tabular}

\section{TABLE 3: Eight studies that reported on the radiographic follow-up of Tillaux fractures}

Unrecorded data are represented by '-'

ORIF, open reduction internal fixation; CRIF, closed reduction internal fixation; PPC, premature physeal closure

\section{Discussion}

The adolescent Tillaux fracture is an uncommon injury and, subsequently, there is a lack of high-quality evidence in the literature. The available data is largely confined to sporadic case reports and small number case series. Data are often presented as a combination of Tillaux and triplane fractures, with many reports lacking robust follow up (see Appendix B) $[18,27,33]$.

Excellent outcomes were seen irrespective of operative modality (ORIF vs. CRIF vs. arthroscopic) in studies reporting patient outcome measures. All five of these studies had patients with $2 \mathrm{~mm}$ or more of fracture displacement as an indication for surgery. Anatomic reduction without persistent articular incongruity in Tillaux fractures appears to be associated with favourable outcomes. Whilst an initial attempt at closed reduction is warranted, it may not always be possible to obtain the reduction; periosteal interposition at the fracture site may prevent reduction and necessitate definitive open reduction. Given the small numbers of patients, it is important to consider that the available literature may not be representative of the real-world Tillaux population; reporting bias may take effect if operative patients with unfavourable outcomes are not reported upon. In addition to this, the mean length of follow-up for patients with reported outcome measures was 3.4 years, which may overlook long-term complications.

It has been suggested that whilst boys have a higher occurrence rate of epiphyseal fractures, the subgroup of Tillaux fractures occurs more frequently in girls [11,37-38]. Our results support this observation, with $58.8 \%$ $(n=67)$ of Tillaux fractures occurring in girls.

A quantitative meta-analysis was considered to provide statistical evidence for the comparative efficacy of 
each type of operative treatment (ORIF, CRIF, arthroscopic). Since there were no recorded cases of adverse radiographic findings for any operative treatment type, only patient outcome measures could feasibly be used as a dependent variable in quantitative analysis. Unfortunately, the total sample for studies recording a patient outcome measure $(n=34)$ was insufficient for the statistical discovery of even relatively large effects. This is further confounded by the presence of a ceiling effect within the distribution of outcome measure scores, indicative of a high success rate amongst all treatment types. The scarcity of cases is a function of the rarity of Tillaux fractures, but from the small quantity of data available, a descriptive review shows all three operative treatment types to be associated with excellent outcomes.

If fracture displacement persists at $2 \mathrm{~mm}$ or more, it should be reduced. Eighty patients had radiographic follow-up reported, and four patients had poor radiographic sequelae. All four of these patients were treated nonoperatively, with three of them having had no attempt at reduction. These three patients had a residual fracture displacement of $2 \mathrm{~mm}$. The abnormalities included poor joint congruity, angular deformity and shortening. There were no reported instances of premature physeal closure in our data. By nature of the demographic of Tillaux fractures, growth arrest appears to be less likely to occur since this injury occurs in older adolescent patients who are close to skeletal maturity [39].

\section{Conclusions}

The adolescent Tillaux fracture is an uncommon fracture to the lateral distal tibial epiphysis. Since these fractures are intraarticular, adequate anatomical reduction should be the primary goal, irrespective of the operative approach. Excellent patient outcomes have been reported for different methods of operative fixation, however, study sizes are small, and data is sparse. Further comparative studies are required to identify definitive conclusions. The use of established clinical and radiographic outcome measures will help improve the quality of future studies for this relatively rare injury.

\section{Appendices}

\section{Appendix A}




\section{Cureus}

\begin{tabular}{|c|c|c|}
\hline Study & $\begin{array}{l}\text { Risk of } \\
\text { bias }\end{array}$ & Comment \\
\hline $\begin{array}{l}\text { Al-Ashhab } \\
\& \\
\text { Mohamed } \\
{[26]}\end{array}$ & Moderate & Presented as a cohort but only single arm with no comparative group \\
\hline $\begin{array}{l}\text { Kim et al. } \\
{[27]}\end{array}$ & Low & - \\
\hline $\begin{array}{l}\text { Tiefenbock } \\
\text { et al. [28] }\end{array}$ & Low & Limited follow-up data (only five of seven available for long term follow-up) \\
\hline $\begin{array}{l}\text { Feng et al. } \\
\text { [29] }\end{array}$ & Low & - \\
\hline $\begin{array}{l}\text { Kaya et al. } \\
\text { [30] }\end{array}$ & High & Unclear selection approach, undefined time period \\
\hline $\begin{array}{l}\text { Gourineni } \\
\text { \& Gupta } \\
\text { [33] }\end{array}$ & Moderate & Comparatively short follow-up period \\
\hline $\begin{array}{l}\text { Leary et al. } \\
\text { [35] }\end{array}$ & Moderate & Operative intervention insufficiently reported \\
\hline $\begin{array}{l}\text { Dailiana et } \\
\text { al. [31] }\end{array}$ & Moderate & Unclear intervention criteria; did not specify fracture displacement requirement for surgery \\
\hline $\begin{array}{l}\text { Stefanich } \\
\text { \& Lozman } \\
\text { [11] }\end{array}$ & High & Unclear selection approach, undefined time period \\
\hline $\begin{array}{l}\text { Landin et } \\
\text { al. [34] }\end{array}$ & High & Selection bias; only 59 of 79 patients came forward for examination \\
\hline $\begin{array}{l}\text { Dias \& } \\
\text { Giegerich } \\
\text { [32] }\end{array}$ & Moderate & Radiographic outcome analysis insufficiently defined (criteria for radiographic evaluation not defined) \\
\hline $\begin{array}{l}\text { Spiegel et } \\
\text { al. [12] }\end{array}$ & Moderate & Inadequate follow-up data (only four of six patients had follow-up outcomes recorded) \\
\hline $\begin{array}{l}\text { Molster et } \\
\text { al. [36] }\end{array}$ & High & $\begin{array}{l}\text { Unclear selection approach, comparatively short follow-up period, radiographic outcome analysis } \\
\text { insufficiently defined, unclear intervention criteria; did not specify fracture displacement requirement for } \\
\text { surgery (defined displacement as moderate or minimal) }\end{array}$ \\
\hline
\end{tabular}

TABLE 4: Quality assessment tool used to assess the risk of bias of the included studies

Appendix B 


\section{Cureus}

\begin{tabular}{|c|c|c|c|}
\hline Article & Year & Journal & Reason for exclusion \\
\hline Lurie et al. 2020 & 2020 & The Journal of Bone and Joint Surgery & $\begin{array}{l}\text { Grouped Tillaux and triplane together for functional } \\
\text { outcome assessment }\end{array}$ \\
\hline Stenroos et al. 2019 & 2019 & Acta Orthopaedica & $\begin{array}{l}\text { Only one patient available for follow-up in Tillaux } \\
\text { group }\end{array}$ \\
\hline Zelenty et al. 2018 & 2018 & Journal of Pediatric Orthopaedics & Could not identify Tillaux group - mixed with triplane \\
\hline $\begin{array}{l}\text { Aguilar Ezquerra et } \\
\text { al. } 2017\end{array}$ & 2017 & Revista de la Facultad de Ciencias Medicas & Foreign language \\
\hline Choudhry et al. 2014 & 2014 & Journal of Pediatric Orthopaedics & Grouped Tillaux and triplane fractures \\
\hline Liporace et al. 2012 & 2012 & Orthopedics & Compared imaging choices, no relevant follow-up \\
\hline Strohm et al. 2011 & 2011 & $\begin{array}{l}\text { Acta chirurgiae orthopaedicae et } \\
\text { traumatologiae Cechoslovaca }\end{array}$ & Grouped Tillaux and triplane fractures \\
\hline Castellani et al. 2009 & 2009 & The Journal of Trauma & Could not identify a Tillaux cohort from the data \\
\hline $\begin{array}{l}\text { Panagopoulos et al. } \\
2008\end{array}$ & 2008 & Injury & Letter to editor \\
\hline Jennings et al. 2007 & 2007 & The Journal of Foot and Ankle Surgery & $\begin{array}{l}\text { Only one Tillaux patient in a case series of six } \\
\text { patients }\end{array}$ \\
\hline Pannier et al. 2006 & 2006 & $\begin{array}{l}\text { Revue de chirurgie orthopedique et reparatrice } \\
\text { de l'appareil moteur }\end{array}$ & Foreign language \\
\hline $\begin{array}{l}\text { Nenopoulos et al. } \\
2005\end{array}$ & 2005 & Journal of Pediatric Orthopaedics & Could not assign follow-up to fracture group \\
\hline Weinberg et al. 2005 & 2005 & Injury & $\begin{array}{l}\text { Grouped treatment outcomes for all transitional } \\
\text { fractures }\end{array}$ \\
\hline Horn et al. 2001 & 2001 & Journal of Pediatric Orthopaedics & Cadaveric study \\
\hline $\begin{array}{l}\text { Schlesinger et al. } \\
1993\end{array}$ & 1993 & Journal of Pediatric Orthopaedics & $\begin{array}{l}\text { Insufficient detail on follow-up and follow-up } \\
\text { assessment }\end{array}$ \\
\hline Melchior et al. 1990 & 1990 & Chirurgie Pediatrique & Foreign language \\
\hline Felman, AH 1989 & 1989 & Pediatric Radiology & Review article \\
\hline Von Laer, L 1985 & 1985 & The Journal of Bone and Joint Surgery & $\begin{array}{l}\text { Could not assign radiographic follow-up to fracture } \\
\text { group }\end{array}$ \\
\hline MacNealy et al. 1982 & 1982 & American Journal of Roentgenology & $\begin{array}{l}\text { Insufficient detail on follow-up and follow-up } \\
\text { assessment }\end{array}$ \\
\hline Letts, RM 1982 & 1982 & Journal of Pediatric Orthopaedics & $\begin{array}{l}\text { Insufficient detail on follow-up and follow-up } \\
\text { assessment }\end{array}$ \\
\hline Kump, WL 1966 & 1966 & American Journal of Roentgenology & $\begin{array}{l}\text { Insufficient detail on follow-up and follow-up } \\
\text { assessment }\end{array}$ \\
\hline Crenshaw, AH 1965 & 1965 & Clinical Orthopaedics and Related Research & Could not identify Tillaux patients \\
\hline $\begin{array}{l}\text { Kleiger, B \& Mankin, } \\
\text { HJ } 1964\end{array}$ & 1964 & The Journal of Bone and Joint Surgery & $\begin{array}{l}\text { Insufficient detail on follow-up and follow-up } \\
\text { assessment }\end{array}$ \\
\hline
\end{tabular}

TABLE 5: List of full-text articles excluded with reasons

\section{Additional Information \\ Disclosures}

Conflicts of interest: In compliance with the ICMJE uniform disclosure form, all authors declare the following: Payment/services info: All authors have declared that no financial support was received from 
any organization for the submitted work. Financial relationships: All authors have declared that they have no financial relationships at present or within the previous three years with any organizations that might have an interest in the submitted work. Other relationships: All authors have declared that there are no other relationships or activities that could appear to have influenced the submitted work.

\section{References}

1. Cooper A: A Treatise on Dislocations and Fractures of the Joints . London, United Kingdom; 1822.

2. Tillaux P: Recherches cliniques et experimentales sur les fractures malleolaires, rapport par gosselin [Article in French]. Bull Acad Med (Paris). 1872, 21:817.

3. Chaput H: Les Fractures Malléolaires du Cou-De-Pied et Les Accidents du Travail [Book in French] . Masson, Paris; 1907.

4. Kleiger B, Mankin HJ: Fracture of the lateral portion of the distal tibial epiphysis . J Bone Joint Surg Am. 1964, 46:25-32.

5. Von Laer L: Classification, diagnosis, and treatment of transitional fractures of the distal part of the tibia . J Bone Joint Surg Am. 1985, 67:687-698.

6. Su AW, Larson AN: Pediatric ankle fractures: concepts and treatment principles. Foot Ankle Clin. 2015, 20:705-719. 10.1016/i.fcl.2015.07.004

7. Ogden JA, McCarthy SM: Radiology of postnatal skeletal development. VIII. Distal tibia and fibula . Skeletal Radiol. 1983, 10:209-220. 10.1007/BF00357893

8. Ogden JA, Lee J: Accessory ossification patterns and injuries of the malleoli . J Pediatr Orthop. 1990, 10:306316. 10.1097/01241398-199005000-00003

9. Rosenbaum AJ, DiPreta JA, Uhl RL: Review of distal tibial epiphyseal transitional fractures . Orthopedics. 2012, 35:1046-1049. 10.3928/01477447-20121120-07

10. Koury SI, Stone CK, Harrell G, La Charité DD: Recognition and management of Tillaux fractures in adolescents. Pediatr Emerg Care. 1999, 15:37-39. 10.1097/00006565-199902000-00011

11. Stefanich RJ, Lozman J: The juvenile fracture of Tillaux. Clin Orthop Relat Res. 1986, 210:219-227.

12. Spiegel PG, Cooperman DR, Laros GS: Epiphyseal fractures of the distal ends of the tibia and fibula. A retrospective study of two hundred and thirty-seven cases in children. J Bone Joint Surg Am. 1978, 60:10461050.

13. Peterson HA: Epiphyseal growth plate fractures. Springer-Verlag, Germany; 2007.

14. Birnie MFN, van Schilt KLJ, Sanders FRK, Kloen P, Schepers T: Anterior inferior tibiofibular ligament avulsion fractures in operatively treated ankle fractures: a retrospective analysis. Arch Orthop Trauma Surg. 2019, 139:787-793. 10.1007/s00402-019-03138-2

15. Habusta SF, Ponnarasu S, Mabrouk A, Griffin EE: Tillaux Fracture. Stat Pearls [Internet], Treasure Island (FL); 2020.

16. Blackburn EW, Aronsson DD, Rubright JH, Lisle JW: Ankle fractures in children . J Bone Joint Surg Am. 2012, 94:1234-1244. 10.2106/JBJS.K.00682

17. Horn BD, Crisci K, Krug M, Pizzutillo PD, MacEwen GD: Radiologic evaluation of juvenile Tillaux fractures of the distal tibia. J Pediatr Orthop. 2001, 21:162-164.

18. Crawford AH: Triplane and Tillaux fractures: is a $2 \mathrm{~mm}$ residual gap acceptable . J Pediatr Orthop. 2012, 32:69-73. 10.1097/BPO.0b013e31824b25a1

19. Kitaoka HB, Alexander IJ, Adelaar RS, Nunley JA, Myerson MS, Sanders M: Clinical rating systems for the ankle-hindfoot, midfoot, hallux, and lesser toes. Foot Ankle Int. 1994, 15:349-353. 10.1177/107110079401500701

20. Hughes JL, Weber H, Willenegger H, Kuner EH: Evaluation of ankle fractures: non-operative and operative treatment. Clin Orthop Relat Res. 1979, 138:111-119.

21. Langenhuijsen JF, Heetveld MJ, Ultee JM, Steller EP, Butzelaar RM: Results of ankle fractures with involvement of the posterior tibial margin. J Trauma. 2002, 53:55-60. 10.1097/00005373-200207000-00012

22. Roos EM, Brandsson S, Karlsson J: Validation of the foot and ankle outcome score for ankle ligament reconstruction. Foot Ankle Int. 2001, 22:788-794. 10.1177/107110070102201004

23. Ouzzani M, Hammady H, Fedorowicz Z, Elmagarmid A: Rayyan-a web and mobile app for systematic reviews. Syst Rev. 2016, 5:210. 10.1186/s13643-016-0384-4

24. Murad MH, Sultan S, Haffar S, Bazerbachi F: Methodological quality and synthesis of case series and case reports. BMJ Evid Based Med. 2018, 23:60-63. 10.1136/bmjebm-2017-110853

25. Sterne JA, Hernán MA, Reeves BC, et al.: ROBINS-I: a tool for assessing risk of bias in non-randomised studies of interventions. BMJ. 2016, 355:4919. 10.1136/bmj.i4919

26. Ali Al-Ashhab ME, Mahmoud Mohamed AA: Treatment for displaced Tillaux fractures in adolescent age group. Foot Ankle Surg. 2020, 26:295-298. 10.1016/j.fas.2019.04.001

27. Kim JR, Song KH, Song KJ, Lee HS: Treatment outcomes of triplane and Tillaux fractures of the ankle in adolescence. Clin Orthop Surg. 2010, 2:34-38. 10.4055/cios.2010.2.1.34

28. Tiefenboeck TM, Binder H, Joestl J, Boesmueller S, Schurz M, Krestan C, Tiefenboeck MM: Displaced juvenile Tillaux fractures: surgical treatment and outcome. Wien Klin Wochenschr. 2017, 129:169-175. 10.1007/s00508-016-1059-9

29. Feng SM, Sun QQ, Wang AG, Li CK: "All-inside" arthroscopic treatment of Tillaux-Chaput fractures: clinical experience and outcomes analysis. J Foot Ankle Surg. 2018, 57:56-59. 10.1053/j.jfas.2017.07.020

30. Kaya A, Altay T, Ozturk H, Karapinar L: Open reduction and internal fixation in displaced juvenile Tillaux fractures. Injury. 2007, 38:201-205. 10.1016/j.injury.2006.07.033

31. Dailiana ZH, Malizos KN, Zacharis K, Mavrodontidis AN, Shiamishis GA, Soucacos PN: Distal tibial epiphyseal fractures in adolescents. Am J Orthop (Belle Mead NJ). 1999, 28:309-312.

32. Dias LS, Giegerich CR: Fractures of the distal tibial epiphysis in adolescence . J Bone Joint Surg Am. 1983, 65:438-444.

33. Gourineni P, Gupta A: Medial joint space widening of the ankle in displaced Tillaux and triplane fractures in children. J Orthop Trauma. 2011, 25:608-611. 10.1097/bot.0b013e318206f8bc 


\section{Cureus}

34. Landin LA, Danielsson LG, Jonsson K, Pettersson H: Late results in 65 physeal ankle fractures . Acta Orthop Scand. 1986, 57:530-534. 10.3109/17453678609014786

35. Leary JT, Handling M, Talerico M, Yong L, Bowe JA: Physeal fractures of the distal tibia: predictive factors of premature physeal closure and growth arrest. J Pediatr Orthop. 2009, 29:356-361.

10.1097/BPO.0b013e3181a6bfe8

36. Molster A, Soreide O, Solhaug JH, Raugstad TS: Fractures of the lateral part of the distal tibial epiphysis (Tillaux or Kleiger fracture). Injury. 1977, 8:260-263. 10.1016/0020-1383(77)90098-5

37. Duchesneau S, Fallat LM: The Tillaux fracture. J Foot Ankle Surg. 1996, 35:127-133. 10.1016/s10672516(96)80029-9

38. Landin LA, Danielsson LG: Children's ankle fractures: classification and epidemiology. Acta Orthop Scand 1983, 54:634-640. 10.3109/17453678308992902

39. Barmada A, Gaynor T, Mubarak SJ: Premature physeal closure following distal tibia physeal fractures: a new radiographic predictor. J Pediatr Orthop. 2003, 23:733-739. 